\title{
Flipbook as Innovation of Digital Learning Media: Preparing Education for Facing and Facilitating 21st Century Learning
}

\author{
Roemintoyo \\ Department of Educational Technology, Sebelas Maret University, Surakarta, Indonesia \\ e-mail: roemintoyo@yahoo.co.id
}

Mochamad Kamil Budiarto

Department of Educational Technology, Sebelas Maret University, Surakarta, Indonesia e-mail: kamilbudiarto@gmail.com

\section{A R T I C L E I N F O \\ Article history: \\ 25 December 2020 \\ Received in revised form \\ 01 January 2021 \\ Accepted 25 January 2021 \\ Available online 03 Pebruari 2021

\begin{tabular}{lr}
\hline Kata Kunci: & \\
Flipbook, & Media \\
Pembelajaran, & Analisis \\
Kebutuhan, & Metode \\
Tradisional &
\end{tabular} \\ Keywords: \\ Flipbook, Instructional \\ Media, Traditional Method, \\ Need-Analysis}

\begin{abstract}
A B S T R A K
Beragam kompetensi yang perlu untuk dikuasai oleh siswa sebagai upaya memperkuat daya saing khususnya pada bidang sumber daya manusia di abad ke -21 . Media pembelajaran yang terintegrasi dengan teknologi menjadi salah satu sumber belajar yang penting untuk menunjang proses belajar. Kurangnya inovasi pemanfaatan media pembelajaran yang terintegrasi dengan teknologi menjadikan kurang optimalnya pencapaian tujuan pembelajaran dan penguasaan kompetensi - kompetensi oleh siswa. Penelitian ini memiliki tujuan untuk mengidentifikasi kebutuhan terhadap peluang pengembangan media pembelajaran yang terintegrasi dengan teknologi berbasis flipbook dengan harapan dapat memperbesar peluang siswa dalam meningkatkan kemampuan literasi sains. Penelitian ini termasuk jenis penelitian kualitatif dengan metode survey. Teknik pengumpulan data menggunakan observasi dan angket analisis kebutuhan. Data kuantitatif dari angket selanjutnya dianalisis menggunakan teknik deskriptif kuantitatif dengan menggunakan persentase yang ditampilkan ke dalam suatu tabel. Subjek penelitiannya mengambil siswa sekolah menengah atas kelas satu dan dua, dengan jumlah 70 siswa. Hasil penelitian ini menunjukkan bahwa $35,7 \%$ siswa menyatakan bahwa guru masih menggunakan media powerpoint dan $27,1 \%$ bahan ajar cetak. Hasil penelitian juga menunjukkan bahwa siswa memiliki persepsi yang positif terhadap peluang pengembangan dan pemanfaatan flipbook sebagai media pembelajaran
\end{abstract} digital. Melalui hasil penelitian ini dapat menjadi dasar dari pendidik dalam mengembangkan dan mengimplementasikan media pembelajaran digital berbasis flipbook untuk memfasilitasi proses belajar.

\section{Introduction}

According to the 2013 Curriculum, learning requires students to practice skills that need to be mastered, therefore in the 2013 curriculum methodologically has implemented a scientific approach (Nurdyansyah \& Fahyuni, 2016). There are various kinds of skills that students must have in digital era, were critical thinking skills, problem solving, being able to communicate, collaboration, creative, scientific literacy, digital literacy, humanitarian literacy and have global awareness (Wijaya, Sudjimat, Nyoto, 2016; Zubaidah, 2018; Suryanti and Wijayanti, 2018).

Entering the digital era as it is today, education needs to adjust to technological developments and advances, where the potential for this technology can create a new learning space needed to facilitate learning activities (Marta, 2019). However, new learning spaces that can be created by technological sophistication must 
be designed based on pedagogical needs (Talebian et al., 2014). The use of ICT in the education aspect has been able to reform the teaching and learning process (Ishaq et al., 2020). In addition, ICT has been able to create various kinds of individual opportunities to be able to learn and access learning resources outside of school (Ghavifekr et al., 2014). The advantage of utilizing ICT is that it can provide a dynamic teaching and learning environment (Shatri, 2020). In line with the potential use of ICT in the learning process, teachers are required to be able to integrate ICT in teaching and replace their traditional methods with more modern tools and facilities (Singh, 2016; Motamedi, 2019).

Science learning is learning that is process and outcome oriented, but now science learning has developed and is attitude oriented (Sari et al., 2017). Science literacy and IT literacy can be developed by each individual, this aims to increase knowledge and investigation of natural science, and so that individuals can understand the relationship between science, technology and society (Yuliati, 2017). One of the subjects that are closely related to the development of scientific literacy and abilities is biology learning. Learning biology as a science cannot be separated from hands on activities, minds on, and hearts on, which involve practical and thinking skills (Jayawardana, 2017). Students need to be active in thinking activities as an effort to improve science skills, so that students can find new concepts through learning activities. Biology learning materials have several characteristics, including material that can be concrete or abstract (Puspita et al., 2017). Abstract material causes students to have difficulty understanding the material. The process of extracting data in the field, which took place in high schools through observation of the implementation of learning, obtained information that teachers still apply traditional learning models which are still unable to encourage students to take an active role in learning activities. This is shown by students who during the learning process were still more passive and only recorded a few points and information about the subject matter delivered by the teacher without actively trying to explore and find new knowledge. On the other hand, the use of learning media during the learning process is still in the form of a power point presentation which tends to be static and simple, this may be a factor in the low curiosity and active participation of students during the learning process.

Textbooks only contain material text with supporting pictures. Module and Student Worksheets contain material summaries, assignments and daily test questions. The power point presented only contains a summary of the material that is less informative, less interesting, and does not encourage students' curiosity about the material being studied. The teaching materials used do not contain supporting material in the form of video (audio visual) to minimize the abstractness of the body's defense system material in humans (Octaviyantari et al., 2020; Junaidi, 2019). Technological developments as they do in all fields affect the education system. This affects the application of computers in educational training and its application in the education system (Yaghoobi \& Razmjoo, 2016). Therefore, it is important to consider other factors that can influence students' motivation to use it apart from technological factors. Sousa \& Rocha (2019) consider digital learning as delivery in the form of digital media (for example text or images) via the Internet; and, the learning content and teaching methods provided are to improve student learning and aim to improve teaching effectiveness or promote personal knowledge and skills. One of the learning media in biology can be information and communication technologybased media (ICT). In the era of information and communication technology (ICT) that has developed rapidly as it is currently possible to be used in biology learning in the form of multimedia-based learning development in a computer context such as Flip Book (Prasetyono \& Hariyono, 2020; Rusli \& Antonius, 2019; Riyanto et al., 2020).

Several studies have shown that the use of digital books packaged in the form of flipbooks has a positive impact on improving the quality of the process and student learning outcomes (Isnaeni \& Agustina, 2018). In addition, the use of flipbook-based digital books with website assistance can improve students' logical thinking skills in mathematics learning (Prasetyono \& Hariyono, 2020). The development of innovative teaching materials will help students prepare for new skills that are relevant in the 21 st century. One of the innovations in the delivery of teaching and learning materials is utilizing an interactive digital e-book called a flipbook which is one of the solutions in science learning as an effort to improve students' critical thinking skills (Riyanto et al., 2020). Based on the various descriptions above, it is important to innovate in the learning process, especially in the delivery of material. The opportunity to use flipbook-based digital teaching materials shows very positive results when applied to the learning process. Because of this, this study aims to identify the need for the development of flipbook-based digital learning media for learning biology in high schools.

\section{Method}

This research is a type of qualitative research with a survey method (Sugiyono, 2018). Participants in this study were 70 public senior high school students consisting of grades one and two in the Surakarta area, Central Java Province. Data collection was carried out in the following manner, observation and questionnaire. The questionnaire was then distributed randomly and through a questionnaire link that had been provided to 70 
high school students. The quantitative data from the questionnaire were analyzed using quantitative descriptive techniques using percentages which were then displayed in tables. Considering that this research only focuses on students 'perceptions of the opportunities for the development and implementation of flipbook-based digital learning media, this causes observation sheets and questionnaires to be designed with points and questions related to the use of instructional media that have been used by teachers, students' perceptions of development and the use of flipbooks as learning media, as well as students' reasons for choosing flipbooks to be developed and used in the learning process.

\section{Result and Discussion}

Based on the results of student questionnaires, it was found that students felt unhappy when learning only using text books, modules or textbooks. This is indicated by the types of instructional media that are often used by teachers in classroom learning.

Table 1. Media frequently used by teachers

\begin{tabular}{lll}
\hline Media Type & F $(\mathbf{N}=\mathbf{7 0})$ & \% \\
\hline Modul Printed & 19 & 27,1 \\
Text Book & 15 & 21,4 \\
Powerpoint & 25 & 35,7 \\
Worksheet & 11 & 15,7 \\
Total & 70 & 100 \\
\hline
\end{tabular}

It can be seen in table 1 . that almost $35.7 \%$ of students stated that in class learning, the teacher used powerpoints to support learning activities, followed by the use of modules, text books and worksheets. Basically students want learning media that contains material and also contains audio visuals such as video as supporting material, so far students have studied biology using learning media other than text books and student worksheets, namely using Microsoft Powerpoint (PPT) for presentations, students state the material There are still many biology lessons that are very abstract when taught which results in obstruction of information processing so that the use of media is needed so that learning becomes clearer and students feel happy if the media used in learning uses the basis of information and communication technology (ICT).

Table 2. Students' perceptions of the flipbook development

\begin{tabular}{lll}
\hline Student's Response & F (N=70) & \% \\
\hline Agree & 58 & 82,9 \\
Neutral & 12 & 17,1 \\
Disagree & 0 & 0 \\
Total & 70 & 100 \\
\hline
\end{tabular}

Almost all students, or $82.9 \%$ of students, agreed to develop and use flipbook-based digital books. Flipbooks are electronic books in the form of soft files while textbooks are in the form of hard files, Flip Books can contain audio files, videos and bibliography in the form of links, so students can directly visit the source website to find out more about the body's defense system in humans, the Flip Book which developed to contain more learning indicators, so that the material presented is more complete. How is the response of the following students who use flipbook-based digital learning media for learning, namely:

Table 3. The attractiveness of the flipbook-based digital media feature

\begin{tabular}{lll}
\hline Reasons for choosing a flipbook & $\mathbf{F ~}(\mathbf{N}=\mathbf{7 0})$ & \% \\
\hline Interactive & 18 & 25,7 \\
There are learning videos & 5 & 7,1 \\
There are practice questions & 6 & 8,6 \\
More attractive appearance & 28 & 40 \\
Not boring when reading text & 13 & 18,6 \\
Total & 70 & 100 \\
\hline
\end{tabular}

From table 3. it is known that there are various reasons students choose flipbook-based digital books to be used in biology learning. The first order was filled with the reason that students chose the flipbook because it 
looked more attractive $(40 \%)$, then there was an interactive element in the media $(25.7 \%)$, then the students stated that the flipbook design was not boring because it did not only contain text, but there were pictures and videos. $(18.6 \% 7.1 \%)$.

The needs analysis also done with conducting field observations. Based on the results of field observations at senior high school, it was found that the teacher had not optimized several aspects of supporting learning, such as the models and learning media used. The learning model applied by the teacher has not been able to encourage students to take an active role in compiling their own knowledge. Students are mostly silent and only record the information given by the teacher without actively trying to explore and find new knowledge. The media used by the teacher in the form of power point presentations is simple, only contains important points and a summary of the material that is minimalist, less interesting, and does not encourage students' curiosity about the material being studied. Based on the results of interviews with teachers, the material for the body's defense system is still considered difficult because it is abstract because it occurs in the body and cannot be directly observed. The learning media used in learning during observation are in the form of text books, modules, student worksheets and power point presentations. The textbook used does not include core competencies, basic competencies and learning indicators. Textbooks only contain material text accompanied by supporting pictures. Module and student worksheets contain a summary of the material, assignments and daily test questions. The power point presented only contains a summary of the material that is less informative, less interesting, and does not encourage students' curiosity about the material being studied. The teaching materials used have not included supporting material in the form of video (audio visual) to minimize the abstractness of the body's defense system material in humans.

The results of the study showed that the low use of digital-based learning media by teachers is very unfortunate considering that in the era of the industrial revolution 4.0 technology is an integral part of human survival (Malik \& Agarwal, 2012; Motamedi, 2019). The media used by the teacher is in the form of media that tends to be traditional and simple, so that it only contains important points and a summary of the material that is minimalist, less interesting, and does not encourage students' curiosity about the material being studied (Nurhidayati et al., 2018). Biology Flip Book Media for Senior High School Class XI IPA on the body's defense system material is arranged based on a module structure, which is divided into three parts, namely introduction, content and closing sections (Rofiah et al., 2018; Sirate \& Ramadhana, 2017).

Even though the use of learning media tends to be still conventional, on the other hand, the media is quite varied because according to the survey the teacher still uses print modules, powerpoints and student worksheets which in each use have advantages and benefits to be able to increase student achievement and interest in learning (Nithyanantham et al., 2019). Interactive media that can be used as learning media in class and integrated with the use of ICT, one of which is a flipbook. Based on the survey results, students had a fairly good view of the plan to use and develop flipbooks in science learning. This certainly cannot be separated from the characteristics of the flipbook as an interactive, technology-based, attractive, easy-to-use, easy-to-use digital learning media that can contain question exercises in addition to the presented material (Saraswati et al., 2019).

As research conducted by Simatupang \& Sormin (2020) stated the use of flipbooks as a learning medium can improve student learning outcomes and skills. In addition, the use of flipbook learning media can also be collaborated with various learning approaches that are tailored to the needs so that it has implications for the achievement of innovative, fun, active learning and is able to facilitate students in achieving a competency (Nurhidayati et al., 2018; Ni'mah et al., 2017; Kurniawati et al., 2016; Susanti et al., 2020). Biology flipbook media serves as an intermediary for delivering material from teachers to students (Rofiah et al., 2018), as a reference and learning resource for students independently (Rusli \& Antonius, 2019; Aprilia et al., 2017). Overall Biology Flipbook for Senior High School class XI IPA on the body defense system material as one of the learning media innovations is needed to support learning in the era of the industrial revolution 4.0 in order to achieve the specified learning objectives. Given that there have been many benefits of flipbook-based electronic modules as learning media to support learning activities. In addition, the element of interactivity of the flipbook can be an added value because this electronic media has multimedia properties, which can be combined with text, narration, video, practice questions and integration with various approaches in the implementation of learning.

\section{Conclusion}

Based on the results of the study, it shows that during the learning process teachers tend to use traditional media and learning models. Several researchers have found empirical facts that using flipbooks as a medium for digital learning has various benefits for students. It is hoped that the results of this research can become a foundation for the continuity of the flipbook product development process to support learning and as a basis for teacher thinking to be able to provide innovation in the implementation of learning. Meanwhile, several 
related studies have shown that the use of flipbooks in the learning process has a positive impact on improving student achievement both academically and practically. Further studies can be carried out by other researchers as a form of development and use of flipbooks for science learning, especially biology and other subjects. The use of innovative digital teaching materials will be able to help students to be more motivated in following the learning process.

\section{References}

Acun, I., \& Karabulut, B. (2012). ICT integration stages of teachers and factors affecting them. Energy Education Science and Technology Part B: Social and Educational Studies.

Aprilia, T., Sunardi, S., \& Djono, D. (2017). Penggunaan Media Sains Flipbook dalam Pembelajaran IPA di Sekolah Dasarr. Teknodika, 15(2), 75. https://doi.org/10.20961/teknodika.v15i2.34749

Ishaq, K., Azan, N., Zin, M., Rosdi, F., Abid, A., \& Ijaz, M. (2020). The Impact of ICT on Students' Academic Performance in Public Private Sector Universities of Pakistan. International Journal of Innovative Technology and Exploring Engineering, 9(3), 1117-1121. https://doi.org/10.35940/ijitee.c8093.019320

Isnaeni, I., \& Agustina, Y. (2018). An increase in learning outcome students is through the development of archive e-module based on the flipbook with discovery learning model. Jurnal Pendidikan Bisnis Dan Manajemen, 4(3), 125-129. https://doi.org/10.17977/um003v4i32018p125

Jayawardana, H. B. A. (2017). Paradigma pembelajaran biologi di era digital. Jurnal Bioedukatika, 5(1), 12. https://doi.org/10.26555/bioedukatika.v5i1.5628

Junaidi, J. (2019). Peran Media Pembelajaran Dalam Proses Belajar Mengajar. Diklat Review: Jurnal Manajemen Pendidikan Dan Pelatihan, 3(1), 45-56. https://doi.org/10.35446/diklatreview.v3i1.349

Kurniawati, H., Desnita, D., \& Siswoyo, S. (2016). Pengembangan Media Pembelajaran Berbasis 3D PageFlip Fisika untuk Materi Getaran dan Gelombang Bunyi. Jurnal Penelitian \& Pengembangan Pendidikan Fisika, 2(1), 97-102. https://doi.org/10.21009/1.02114

Malik, S., \& Agarwal, A. (2012). Use of Multimedia as a New Educational Technology Tool-A Study. International Journal of Information and Education Technology, 2(5), 468-471. https://doi.org/10.7763/ijiet.2012.v2.181

Marta, L. C. (2019). The Integration of digital devices into learning spaces according to the needs of primary and secondary teachers. TEM Journal, 8(4), 1351-1358. https://doi.org/10.18421/TEM84-36

Motamedi, V. (2019). The promises of presentational technology for teaching and learning. Journal of Education and Learning (EduLearn), 13(3), 416-419. https://doi.org/10.11591/edulearn.v13i3.13175

Ni'mah, D. T. S., Sutrisno, S., \& Shodiqin, A. (2017). Pengembangan modul matematika berbantu flipbook maker dan prezi dengan model kooperatif teknik kancing gemerincing pada materi peluang smk kelas $\mathrm{x}$. AKSIOMA, 6(2), 18. https://doi.org/10.26877/aks.v6i2.1399

Nithyanantham, V., Paulmony, R., \& Ramadan H., S. (2019). Self-Perspective of 21st Century Educators: A Challenge in The Globalised Educational World. International Journal of Educational Research Review, 4(3), 325-333. https://doi.org/10.24331/ijere.573869

Nurdyansyah, \& Fahyuni, E. F. (2016). Inovasi Model Pembelajaran Sesuai Kurikulum 2013. In Nizmania Learning Center.

Nurhidayati, A., Putro, S. C., \& Widiyaningtyas, T. (2018). Penerapan model pbl berbantuan e-modul berbasis flipbook dibandingkan berbantuan bahan ajar cetak pengaruhnya terhadap hasil belajar pemrograman siswa smk. Teknologi Dan Kejuruan: Jurnal Teknologi, Kejuruan, Dan Pengajarannya, 41(2), 130138. https://doi.org/10.17977/um031v41i22018p130

Octaviyantari, N. L. A., Suarni, N. K., \& Widiana, I. W. (2020). Improving Social Studies Learning Outcomes Through Group Investigation Learning Model Assisted with Audio-Visual Media. Journal of Education Technology, 4(3), 349-358. https://doi.org/10.23887/jet.v4i3.25245

Prasetyono, R. N., \& Hariyono, R. C. S. (2020). Development of flipbook using web learning to improve logical thinking ability in logic gate. International Journal of Advanced Computer Science and Applications. https://doi.org/10.14569/ijacsa.2020.0110143 
Puspita, A., Kurniawan, A. D., \& Rahayu, H. M. (2017). Pengembangan media pembelajaran booklet pada materi sistem imun terhadap hasil belajar siswa kelas xi sman 8 pontianak. Jurnal Bioeducation, 4(1). https://doi.org/10.29406/524

Riyanto, R., Amin, M., Suwono, H., \& Lestari, U. (2020). The New Face of Digital Books in Genetic Learning: A Preliminary Development Study for Students' Critical Thinking. International Journal of Emerging Technologies in Learning (IJET), 15(10), 175. https://doi.org/10.3991/ijet.v15i10.14321

Rofiah, E., Aminah, N. S., \& Sunarno, W. (2018). Pengembangan modul pembelajaran ipa berbasis high order thinking skill (hots) untuk meningkatkan kemampuan berpikir kritis siswa kelas viii smp/mts. INKUIRI: Jurnal Pendidikan IPA, 7(2), 285. https://doi.org/10.20961/inkuiri.v7i2.22992

Rusli, M., \& Antonius, L. (2019). Meningkatkan Kognitif Siswa SMAN I Jambi Melalui Modul Berbasis EBook Kvisoft Flipbook Maker. Jurnal Sistem Komputer Dan Informatika (JSON). https://doi.org/10.30865/json.v1i1.1397

S.Sirate, S. F., \& Ramadhana, R. (2017). Pengembangan modul pembelajaran berbasis keterampilan literasi. Inspiratif Pendidikan, 6(2), 316. https://doi.org/10.24252/ip.v6i2.5763

Saraswati, S., Linda, R., \& Herdini, H. (2019). Development of Interactive E-Module Chemistry Magazine Based on Kvisoft Flipbook Maker for Thermochemistry Materials at Second Grade Senior High School. Journal of Science Learning, 3(1), 1-6. https://doi.org/10.17509/jsl.v3i1.18166

Sari, D. N. A., Rusilowati, A., \& Nuswowati, M. (2017). Pengaruh Pembelajaran Berbasis Proyek terhadap Kemampuan Literasi Sains Siswa. PSEJ (Pancasakti Science Education Journal), 2(2), 114. https://doi.org/10.24905/psej.v2i2.741

Shatri, Z. G. (2020). Advantages and disadvantages of using information technology in learning process of students. Journal of Turkish Science Education, 17(3), 420-428. https://doi.org/10.36681/tused.2020.36

Singh, R. (2016). Learner and Learning in Digital Era : Some Issues and Challenges. International Education \& Research Journal [IERJ], 2(10), 92-94. http://ierj.in/journal/index.php/ierj/article/view/508

Simatupang, I. N., \& Sormin, E. (2020). The effectiveness of using flipbook maker to improve the chemistry learning outcomes of senior high school students. Jurnal Pendidikan Kimia, 12(1), $26-33$. https://doi.org/10.24114/jpkim.v12i1.17710

Sousa, M. J., \& Rocha, Á. (2019). Digital learning: Developing skills for digital transformation of organizations. Future Generation Computer Systems, 91, 327-334. https://doi.org/10.1016/j.future.2018.08.048

Sugiyono, D. (2018). Metode penelitian kuatintatif, kualitatif dan R \& D. Bandung: Alfabeta.

Suryanti, \& Wijayanti, L. (2018). Literasi Digital : Kompetensi Mendesak Di Era Revolusi Industri 4.0. Jurnal Pendidikan Dasar.

Susanti, N., Yennita, Y., \& Azhar, A. (2020). Development of Contextual Based Electronic Global Warming Modules Using Flipbook Applications as Physics Learning Media in High Schools. Journal of Educational Sciences, 4(3), 541. https://doi.org/10.31258/jes.4.3.p.541-559

Talebian, S., Mohammadi, H. M., \& Rezvanfar, A. (2014). Information and Communication Technology (ICT) in Higher Education: Advantages, Disadvantages, Conveniences and Limitations of Applying Elearning to Agricultural Students in Iran. Procedia - Social and Behavioral Sciences, 152, 300-305. https://doi.org/10.1016/j.sbspro.2014.09.199

Wijaya, E. Y., Sudjimat, D. A., \& Nyoto, A. (2016). Transformasi Pendidikan Abad 21 Sebagai Tuntutan. Jurnal Pendidikan, 1, 263-278.

Yaghoobi, M., \& Razmjoo, S. A. (2016). The potentiality of computer-assisted instruction towards ameliorating Iranian EFL learners' reading level. Computers in Human Behavior, 59, 108-114. https://doi.org/10.1016/j.chb.2016.01.033

Yuliati, Y. (2017). Literasi sains dalam pembelajaran ipa. Jurnal Cakrawala Pendas, 3(2). https://doi.org/10.31949/jcp.v3i2.592

Zubaidah, S. (2018). Mengenal 4C: Learning and Innovation Skills untuk Menghadapi Era Revolusi Industri 4.0. 2nd Science Education National Conference, April, 1-18. 